ROCZNIKI PEDAGOGICZNE

Tom 13(49), numer $4-2021$

DOI: http://doi.org/10.18290/rped21134.8

MAŁGORZATA CYWIŃSKA

\title{
DZIECKO W SYTUACJI ROZWODU RODZICÓW
}

\section{WPROWADZENIE}

Rodzina stanowi ogromną wartość egzystencjalną dla każdej jednostki ludzkiej. Jest też najbardziej intymnym środowiskiem życia. Jej niepowtarzalność zawiera się $\mathrm{w}$ wyjątkowych, unikatowych interakcjach i w charakterystycznym sposobie pełnienia podstawowych funkcji oraz zaspokajania potrzeb jej członków. Niestety to fundamentalne, prymarne środowisko życia człowieka coraz częściej okazuje się niestabilne, nietrwałe i nieodporne na wyzwania współczesności. Dominujące we współczesnym świecie wieloznaczność, niedookreśloność, procesy rywalizacyjne, antagonistyczne stosunki interpersonalne powodujące poczucie zagrożenia, zagubienia, niepewność (Melosik, 2003, s. 459-463; Melosik, 1995, s. 20-21; Śliwerski, 2004, s. 358-376) niejednokrotnie wyzwalają dysfunkcjonalność tej wyjątkowej przestrzeni rodzinnej. Może ona odzwierciedlać się między innymi w obszarze małżeńskim, rodzicielskim, opiekuńczym, wychowawczym (Nowak, 2012, s. 5255). Dlatego też coraz częściej wydarzenie rozwodu staje się elementem cyklu rozwoju życia człowieka i jego rodziny. Należy dodać, iż na przestrzeni lat zmienił się wewnątrzrodzinny system wartości. Obecnie często dominuje przekonanie, że życie małżeńskie powinno tak długo toczyć się dopóki zapewnia pełną satysfakcję obojgu małżonkom. Coraz rzadziej małżonkowie, przeżywający trudności w związku, podejmują działania mające na celu odbudowanie więzi i poradzenie sobie z kryzysem. Częściej sięgają po rozwiązanie ostateczne - rozwód. Maria Beisert, analizując problematykę rozwodu, akcentuje sześć typów tego wydarzenia, z których każdy stanowi inny jakościowo krąg znamionujący określone działania osób znajdujących się w kryzysie. Obejmują one:

Prof. dr hab. Malgorzata CrwiŃska - Zakład Pedagogiki Dziecka, Wydział Studiów Edukacyjnych Uniwersytetu im. Adama Mickiewicza w Poznaniu; adres do korespondencji: ul. Szamarzewskiego 89, 60-568 Poznań; e-mail: cywinska@amu.edu.pl; ORCID: https://orcid.org/0000-0002-3763-9655 
- rozwód emocjonalny ukazujący proces oddalenia się od siebie partnerów, zanik pozytywnych uczuć pomiędzy małżonkami, zaprzestanie angażowania się ich w małżeństwo oraz pojawienie się w relacjach małżeńskich niechęci i obojętności;

- rozwód legalny odzwierciedlający fakt społeczno-prawny potwierdzający, że decyzja o rozstaniu jest niezmienna i nie dotyczy już tylko sfery życia prywatnego;

- rozwód rodzicielski dotyczący zmian występujących w relacjach rodzicedzieci i odnoszący się do ustaleń związanych $\mathrm{m}$. in. z miejscem zamieszkania dzieci, określeniem typu opieki, ustanowieniem rodzica opiekuńczego;

- rozwód ekonomiczny związany ze zmianami w obrębie kwestii materialnych rodziny, podziałem majątku i często pogorszeniem poziomu zaspokajania potrzeb poszczególnych jej członków;

- rozwód środowiskowy obejmujący zmiany następujące w życiu towarzyskim rozwiedzionych osób i przejścia od statusu osoby zamężnej/żonatej do osoby rozwiedzionej - rozwódki/rozwodnika;

- rozwód psychiczny wyrażający proces uzyskiwania psychicznej autonomii poprzez odseparowanie się od wpływów byłego partnera; przejawia się w rekonstrukcji własnej tożsamości, zmianach w poziomie samooceny, zmaganiu się z silnymi negatywnymi uczuciami oraz tworzeniu nowych planów na przyszłość (Beisert, 2000, s. 96-98).

Z powyższego wynika jak wydarzeniem przełomowym w życiu każdego członka rodziny jest rozwód i jak wiele zmian powoduje $w$ dotychczasowym funkcjonowaniu. Rozpatrywany z indywidualnego punktu widzenia jest punktem krytycznym, zwrotnym w życiu jednostki, bowiem zmianie ulega jej dotychczasowa sytuacja emocjonalna, społeczna, ekonomiczna (Beisert, 1994 a; Beisert, 1994 b). W perspektywie diadycznej rozwód oznacza cykl przemian, bowiem każdy z partnerów musi przejść proces żałoby po stracie jakiej doświadczył, pogodzić się z niespełnieniem nadziei i marzeń dotyczących związku małżeńskiego. Z kolei rozwód, rozpatrywany z perspektywy rodzinnej, ukazuje przemiany jej struktury, zmiany dotyczące formuły życia rodzinnego, które przestaje być wspólnym życiem wszystkich członków rodziny, a odsłania perspektywę życia oddzielnego z wykluczeniem więzi małżeńskiej rodziców. Dla dorosłych członków rodziny rozwód stanowi utratę związku, w którym pokładano nadzieję na trwałość, satysfakcję $z$ bycia razem, dla dzieci natomiast rozwód oznacza utratę pełnej rodziny - strefy zapewniającej bezpieczeństwo i możliwość harmonijnego rozwoju. 


\section{BEZPOŚREDNIE I ODROCZONE W CZASIE SKUTKI ROZWODU RODZICÓW DLA FUNKCJONOWANIA DZIECKA}

Judith S. Wallerstein - prekursorka badań nad rozwodami - prezentując wyniki długofalowych badań wpływu rozwodów na los dzieci podaje następujące skutki bezpośrednie tych trudnych wydarzeń. Stwierdza, że:

- wiele dzieci obwinia się za rozwód rodziców. Dzieci potrafią łatwo przypisywać sobie odpowiedzialność za istnienie konfliktów między rodzicami szczególnie, gdy były świadkami kłótni o sposób ich wychowania;

- wiele dzieci doświadcza poczucia odrzucenia, gdy rodzice się rozwodzą. Traktują rozwód jak działanie skierowane przeciwko nim. Poczucie bycia odrzuconym dotyczy przede wszystkim rodzica, który doprowadził do rozwodu i zdecydował się opuścić rodzinę. Dzieci tęsknią za nim i boją się, że już nigdy go nie spotkają;

- wiele dzieci nie rozumie powodu rozstania, gdy w domu nie było jawnego problemu, konfliktu czy przemocy. Duża część rodziców nie przygotowuje dzieci do nowej sytuacji, niczego nie tłumaczy, nie wyjaśnia, nie wspiera w budowaniu realistycznego myślenia o życiu po rozstaniu, ani nie dba o uczucia dziecka w tym okresie. Uraz, jakiego doznaje dziecko w momencie wyprowadzki z domu jednego z rodziców, mógłby zostać zminimalizowany, gdyby rodzice odpowiednio zaaranżowali tę sytuację;

- wiele dzieci w okołorozwodowym okresie czuje się ogromnie osamotnionych. Nikt ich nie słucha, nie pyta o zdanie, nie bierze pod uwagę ich uczuć, nie ma dla nich czasu. Rodzice zajęci własnymi uczuciami, układaniem nowego życia, a często walką z partnerem, zwykle nie są w stanie ich wspierać;

- wiele dzieci po rozpadzie struktury rodziny traci podstawę do właściwego rozwoju. Struktura rodziny jest dla dziecka podstawą budowania jego tożsamości, źródłem wzorców, które dziecko przenosi w swoje dorosłe życie. Daje wyposażenie w postaci systemu wartości, stylu życia. Pozbawione tej struktury dziecko doświadcza chaosu i zachwiania poczucia bezpieczeństwa, czuje się zagubione, zdane tylko na siebie;

- generalnie dzieci przeżywają rozwód bardzo boleśnie, nie traktują go jako drugiej szansy, jaką bywa czasem dla dorosłych. Przeżywają w związku z nim całą gamę negatywnych uczuć o dużym nasileniu (Wallerstein, 1989, s. 97-122).

Opisu stanu emocjonalnego dzieci, jako konsekwencji sytuacji rozwodowych ich rodziców, dokonał Henryk Cudak. Według badań autora wiele dzieci z rodzin rozbitych bardzo często odczuwa smutek (34\% - prawie pięciokrotnie częściej niż dzieci z rodzin pełnych), pustkę i poczucie beznadziei (29,3\%), brak poczucia sensu życia $(28,2 \%)$ oraz lęk i niepokój $(21,3 \%)$. Ponadto dzieci te mają znacznie niższe poczu- 
cie emocjonalnej bliskości z rodzicami $(9,4 \%)$ niż dzieci z rodzin pełnych $(58,1 \%$ - dzieci z rodzin pełnych sześciokrotnie częściej czują emocjonalną bliskość z rodzicami). Ich radosne wewnętrzne odczucia są przytłumione przez stany depresyjne. H. Cudak wykazuje, że dzieci z rodzin pełnych okazują radość prawie dwa razy częściej (21,8\%) niż z rodzin rozbitych $(11,1 \%)$. Z badań autora wynika również, iż dzieci z rodzin rozbitych prawie trzykrotnie rzadziej (12,2\%) niż dzieci z rodzin pełnych (35,3\%) mają poczucie wewnętrznego spokoju (Cudak, 2010, s. 112-113). Z badań Urszuli Sokal wynika ponadto, że dzieci z rodzin rozwiedzionych podkreślały brak wystarczającego zainteresowania rodziców ich sprawami. W przypadku rodzin niepełnych aż 77\% dzieci stwierdziło, że było ono niewystarczające, natomiast dzieci z rodzin pełnych taki brak odczuwały tylko w 29,7\% (Sokal, 2005, s. 87-89). Jak podaje Sharlene A. Wolchik dzieci z rozbitych rodzin są bardziej agresywne $\mathrm{w}$ stosunku do nauczycieli i innych dorosłych, bardziej podatne na depresję, mają więcej problemów z nauką, często odchodzą ze szkół, cierpią na większe problemy emocjonalne niż ich rówieśnicy z pełnych rodzin (Wolchik, 2002, s. 1874-1881).

Badania Jadwigi Izdebskiej (podobnie jak badania J.S. Wallerstein) dotyczące omawianego aspektu życia rodzinnego dowodzą, iż prawie wszystkie badane dzieci (97\%) czują się osamotnione z powodu rozwodu rodziców - po odejściu ojca („osamotnienie to brak ojca”), bardzo przeżywają tę sytuację, która wywołuje u nich, co wynika z badań autorki, przede wszystkim smutek („,bo tata odszed’”), poczucie krzywdy oraz „pustkę w domu” („osamotnienie to pustka w domu po odejściu taty”) (Izdebska, 2004, s. 93-95). Rozwód rodziców wpływa również niekorzystnie na kontakty dziecka z kolegami bowiem, jak się okazuje, jest ono odmiennie traktowane przez rówieśników („Wszyscy koledzy wiedzieli o rozwodzie, były docinki”, „koleżanki wiedzą o rozwodzie rodziców, rozmawiają o tym za moimi plecami”) (Izdebska, 2004, s. 97). Dzieci z rodzin rozwiedzionych czując upokorzenie, wstyd z powodu rozpadu więzi małżeńskiej ich rodziców, uważając się za gorsze, mniej wartościowe, unikają (zwłaszcza w pierwszym okresie po rozwodzie) kontaktów z rówieśnikami, czasem z sąsiadami, znajomymi. Rozwód rodziców powoduje określone negatywne skutki dla dziecka także w aspekcie materialnym, bowiem status rodziny w tym względzie niejednokrotnie się obniża. A to z kolei pociąga za sobą konieczność większego zaangażowania zawodowego ze strony matki i łączy się z mniejszą ilością czasu poświęcanego dziecku, które czuje się w związku z tym jeszcze bardziej opuszczone i osamotnione. Po rozwodzie zmienia się też sytuacja dziecka odnośnie do czasu wolnego, który znacznie maleje na skutek konieczności podejmowania przez nie szeregu obowiązków rodzinnych, prac domowych, dotąd wykonywanych przez matkę. $Z$ reguły niskie (lub znacznie niższe) dochody rodziny wskutek jej 
rozpadu uniemożliwiają zapewnienie dziecku atrakcyjnego sposobu spędzania wolnego czasu, który - jak wykazały badania J. Izdebskiej - dzieci bardzo rzadko spędzają z ojcem (2004, s. 95-96).

Ból emocjonalny dzieci z rodzin rozbitych jest bardzo głęboki, bowiem wszystkie ich dotychczasowe relacje międzyosobowe zostają naruszone:

- z matką, która będąc zmuszona do radzenia sobie w nowej sytuacji, z reguły nie poświęca dziecku tyle czasu, zainteresowania, wsparcia, ile ono oczekiwałoby;

- z ojcem, którego brak odczuwa bardzo dotkliwie i z którym spotyka się $\mathrm{z}$ reguły okazjonalnie;

- z grupą rówieśniczą komentującą życie rodzinne dziecka, niejednokrotnie stosującą wobec niego różne zachowania restrykcyjne, tym samym nie zapewniającą mu również na tym gruncie poczucia bezpieczeństwa.

Sytuacja powyższa zaburza dziecku prawidłowy obraz relacji rodzinnych, obraz relacji małżeńskich, rodzicielskich, stanowiąc dla niego transmisję nieprawidłowych wzorców w tym względzie, często na zawsze deformując jego relacje interpersonalne.

W analizie zagadnień dotyczących rozwodu należy zaakcentować także skutki całego cyklu tych sytuacji, ujawniające się nie bezpośrednio w ich trakcie, a po wielu latach od ich zaistnienia. J.S. Wallerstein wykazuje na podstawie badań własnych szereg tego rodzaju skutków. Stwierdziła m.in., że:

- u części dzieci, które sprawiały wrażenie dobrze radzących sobie z tą sytuacją wystąpił tzw. „efekt śpiocha”, objawy stresu wydobyły się z dużą siłą po latach od rozwodu. Odroczone skutki rozwodu objawiają się przede wszystkim w sferze bliskich związków;

- po 10 latach 2/3 badanych miało słabe relacje z ojcami, niezależnie od częstotliwości kontaktów;

- u badanych wystąpiły obawy dotyczące odrzucenia i zdrady we własnych związkach, lęk przed porażką i złym wyborem partnera;

- młode osoby, które były świadkami przemocy między rodzicami często odkrywają, że te wczesne obrazy dominują także w ich związkach 10 i 15 lat później;

- przeżycia z czasu okołorozwodowego - kłótnie, bójki, krzyki, wyprowadzka rodzica - zapisują się w doświadczeniu młodych ludzi jako uraz i wracają często w snach i przykrych wspomnieniach bardzo dotkliwie;

- wiele $\mathrm{z}$ nich wchodziło $\mathrm{w}$ dorosłość $\mathrm{z}$ bagażem nieprzepracowanych uczuć; dotyczyło to szczególnie gniewu i wściekłości wynikającego z cierpienia i rozczarowania (gniew z powodu zdrad, oszukiwania, nielojalności, braku odpowiedzialności rodziców); 
- niemal połowa badanych wchodziła w dorosłość z obniżoną samooceną i niższymi osiągnięciami niż ich rówieśnicy bez doświadczenia rozwodu (Wallerstein, 1989, s. 97-122).

Skutki rozwodu rodziców, odczuwane przez ich dzieci w dorosłym życiu, wykazują też badania Józefy Brągiel i pokazują, że najintensywniej w dorosłości odczuwają zaburzenia osobowości $(80 \%)$ oraz negatywny obraz własnej osoby (78\%). Rozwód rodziców - według badanych - miał znaczący wpływ na picie alkoholu (64\%), pojawienie się problemów w pracy (66\%), problemów w małżeństwie (62\%) i współżyciu seksualnym (62\%). Okres rozwodu z perspektywy czasu wspominany był przez dorosłe dzieci jako przeżycie traumatyczne. W badaniach przeprowadzonych przez J. Brągiel 100\% badanych twierdziło, że rozwód rodziców przyniósł poczucie nieszczęścia, a 94\% badanych podkreślało, iż odczuwało strach oraz poczucie bezsilności. A przy tym, co szósta osoba spośród badanych pragnęła własnej śmierci (Brągiel, 2004, s. 200). Wykazano także, iż osoby $\mathrm{z}$ rozbitych rodzin $\mathrm{w}$ dorosłości rzadziej wstępowały $\mathrm{w}$ związek małżeński i częściej się rozwodziły oraz doświadczały poważniejszych i częstszych problemów psychicznych niż osoby wychowane w rodzinach pełnych (Keith, Finlay, 1988, s. 797-809).

\section{2. „PRZETARGI O DZIECKO” JAKO SZCZEGÓLNY WYMIAR SYTUACJI ROZWODOWYCH}

Szczególnie traumatyzującą jest sytuacja, w której dziecko staje się obiektem sporów i rywalizacji pomiędzy rodzicami. Zdarza się, że rodzice mniej lub bardziej świadomie angażują dzieci w swoje sprawy, oczekując od nich wsparcia i opowiedzenia się po „właściwej” stronie. Z badań Mirosławy Nowak-Dziemianowicz wynika, że najczęstszymi zachowaniami osób, które się rozwiodły, są zachowania przepełnione wrogością, niechęcią, często nienawiścią, pragnieniem odwetu. „Nigdy nie wybaczę tego, co mi zrobił. Jeszcze mi za to zapłaci, jeśli jest sprawiedliwość, to jego spotka krzywda”; „Myślę, że będę jej mógł odpłacić za to rajskie życie, jakie mi stworzyła”. Ten typ zachowań związany jest z występowaniem silnych emocji negatywnych oraz obecnością zachowań agresywnych. Autorka przypisuje mu określenie: „zrobiłeś mi krzywdę, jesteś moim wrogiem” (Nowak-Dziemianowicz, 1994, s. 125). W takich sytuacjach dziecko staje się instrumentem przetargowym, „fantem w grze”, angażowane jest często w sprawy rozwodzących się małżonków, co odzwierciedla m.in. dążenie przez jednego lub oboje rodziców do uczynienia z dziecka swego powiernika, osoby stojącej po tej samej stronie w małżeńskim pojedynku. 
Gdy rywalizują o opiekę nad dzieckiem, oboje rodzice starają się dowieść otoczeniu, dzieciom, byłemu partnerowi i sobie samemu, że kierują się jedynie dobrem dziecka. Należy podkreślić również, iż dzieci niejednokrotnie wciągane są w konflikt lojalności między rodzicami, w związku z czym przeżywają napięcie, wstyd, poczucie winy. Często jedynym sposobem pozbycia się poczucia nielojalności w stosunku do głównego opiekuna, zapewniającego elementarne poczucie bezpieczeństwa, jest przyjęcie jego wizji świata i jego sposobu argumentacji, co bywa tożsame z koniecznością dewaluacji i odrzucenia opiekuna drugoplanowego (patologiczne poczucie lojalności). Mechanizm ten stał się podłożem zjawiska opisywanego w literaturze przedmiotu jako zespół alienacji rodzicielskiej - syndrom odosobnienia od jednego z rodziców - przedstawiany przez Richarda Gardnera. Zaburzenia występujące $u$ dziecka ze względu na przesadzone angażowanie go w dewaluację i krytykę drugiego opiekuna objawiają się:

- deprecjonowaniem drugiego opiekuna, znieważaniem go i poniżaniem w wypowiedziach bez poczucia winy czy zakłopotania;

- izolowaniem się bezpośrednim i pośrednim od drugiego opiekuna (nieprzyjmowaniem od niego prezentów, kartek z życzeniami, telefonów);

- przejmowaniem oskarżeń pod adresem drugiego opiekuna płynących od opiekuna „głównego";

- spostrzeganiem rodziców w czarno-białych barwach (Czerederecka, 1999, s. 5).

Na powstanie owych zaburzeń w zachowaniu dziecka mają wpływ podejmowane przez głównego opiekuna takie działania, jak:

- „pranie mózgu” dziecku (drastyczne nastawianie dziecka przeciw drugiemu opiekunowi);

- szantaż emocjonalny i/lub materialny stosowany wobec dziecka;

- wymierzanie kar dziecku za okazywanie pozytywnych emocji wobec drugiego partnera;

- niedopuszczanie drugiego opiekuna do spotkań z dzieckiem;

- przedstawianie drugiego opiekuna w skrajnie niekorzystnym świetle;

- okazywanie dystansu wobec dziecka, okazywanie mu zawodu z powodu nawiązywania pozytywnych kontaktów z drugim rodzicem (Czerederecka, 1999, s. 6).

Rozwód powinien być rozpatrywany jako proces dający możliwość wyodrębnienia etapu przedrozwodowego (okresu przeddecyzyjnego), etapu rozwodowego (czasu obejmującego toczące się postępowanie sądowe) oraz porozwodowego, kiedy to rodzina zmaga się z powrotem do równowagi. Wszystkim wymienionym etapom mogą towarzyszyć rodzinne sytuacje konfliktowe o różnym nasileniu. Często w kwestie sporne rodziców wciągane są dzieci występujące niejednokrotnie $\mathrm{w}$ roli koalicjanta jednego $\mathrm{z}$ nich lub $\mathrm{w}$ roli sędziego bądź też mediatora między rodzicami. W pierwszym przypadku dziecko wchodzi w koalicję z tym rodzicem, 
którego w danym momencie postrzega jako słabszego, potrzebującego wsparcia czy ratunku przed drugim rodzicem. W drugim przypadku dziecko podejmuje próbę rozstrzygania lub łagodzenia sporów między rodzicami. „Dziecko, pośrednicząc czy wręcz mediując między matką i ojcem, narażone jest na obciążenia związane z konfliktem lojalności” (Siewierska, Śliwczyńska, Misiec, Namysłowska, 2012, s. 92). Wchodząc w koalicję z jednym rodzicem dziecko naraża się na wejście w konflikt z drugim „wrogim” rodzicem. Należy też zauważyć, iż dziecko może doświadczać wyładowywania na sobie „konfliktowych” frustracji dorosłych. W skrajnych przypadkach mogą one przybrać postać przemocy fizycznej, psychicznej przejawiającej się np. w szczególnie dotkliwych karach wymierzanych dziecku. W złagodzonej formie może to być sporadyczne bicie, różne co do obszaru ciała i zastosowanej siły, jak i szarpanie, popychanie dziecka, użycie krzyku jako wzmocnienia z całym repertuarem wyzwisk. Zachowania takie mogą powodować u dzieci wewnętrzny rozdźwięk. Opiekun, będący jednocześnie źródłem ukojenia i niepokoju, wywołuje sprzeczne reakcje w zachowaniu dziecka. Pobudzona potrzeba ucieczki przed rodzącym niepokój opiekunem ściera się z potrzebą poszukiwania u niego schronienia i pociechy. W ten sposób dziecko znajduje się emocjonalnie w sytuacji bez wyjścia. Doświadcza swojego opiekuna jako kogoś, kto w pewnych sytuacjach budzi strach. Rozpiętość takich zachowań jest bardzo duża - od zakradania się od tyłu i łapania za szyję do fizycznej przemocy, a nawet seksualnego wykorzystania (Senator, 2010, s. 46).

Sytuacja konfliktu między rodzicami, wzajemne żale i chęć odwetu na byłym partnerze sprawiają, że rodzice często są nieczuli na potrzeby dziecka i w poczuciu ochrony jego interesów - mniej czy bardziej świadomie - wyrządzają mu krzywdę. Dzieci, które powinny znajdować się pod szczególną ochroną, stają się obiektem manipulacji, indoktrynacji i instrumentem w konflikcie rodziców. Przestają się liczyć ich uczucia i potrzeby, na plan pierwszy natomiast wysuwają się zranione uczucia rozwodzących się małżonków. Sytuacja ta jest o tyle dramatyczna, że dzieci są manipulowane przez osoby, które z racji więzi i obowiązków prawnych, powinny je chronić.

\section{FORMY WSPARCIA RODZIN I ICH DZIECI W SYTUACJACH ROZWODOWYCH}

Wsparcie rodziny w sytuacjach rozwodowych, a tym samym wychowujących się w niej dzieci powinno być wszechstronne i wielopłaszczyznowe. Zawsze należy mieć na uwadze dobro dziecka, dlatego wszelkie działania wspierające powinny być temu podporządkowane. Myśląc o pomocy osobom i całym rodzinom, uwikłanym 
w rozwód, właściwym wydaje się spoglądać na ów proces pomocy w kategoriach wyzwań albo zadań stawianych jednostkom $\mathrm{w}$ celu poradzenia sobie $\mathrm{z}$ tą sytuacją. Dorośli mają do wykonania dwa zadania: pierwsze - polegające na odbudowaniu swojego życia, a drugie - dotyczące ochrony dzieci przed niszczącymi skutkami rozwodu. Im lepiej dorośli poradzą sobie z odzyskaniem kontroli nad własnym życiem, tym efektywniej pomogą swoim dzieciom rozpocząć nowy etap ich życia. Ważne, aby rodzice mieli świadomość, iż można złagodzić niekorzystne skutki rozwodu dzieciom, gdy:

- wyłączy się je z konfliktów małżeńskich;

- prowadzi się otwarte, zapewniające poczucie bezpieczeństwa rozmowy $\mathrm{z}$ dzieckiem przed rozwodem;

- przyjmuje się jednakowe lub podobne postawy wychowawcze;

- przestrzega się ustalonych zasad dotyczących wizyt z dzieckiem;

- nie rozdziela się rodzeństwa;

- nie wprowadza się do domu nowego partnera zbyt gwałtownie;

- nie wyraża się negatywnych opinii o byłym małżonku;

- wspiera się emocjonalnie dzieci w okresie rozwodu i w czasie następującym po nim;

- rodzice wykazują umiejętność radzenia sobie z własnymi, negatywnymi emocjami (Pohorecka, 1994, s. 114-115).

Jedną z propozycji, mającą na celu wsparcie rodziców w zakresie wychowania ich dziecka i opieki nad nim w sytuacji samego rozwodu, a szczególnie już po tym wydarzeniu, jest rodzicielski plan wychowawczy zdefiniowany jako „porozumienie o sposobie wykonywania władzy rodzicielskiej i utrzymywania kontaktów z dziećmi po rozwodzie" (Rodzicielski Plan Wychowawczy..., 2009, s. 1). Ma on na celu zagwarantowanie dzieciom pewnej dozy stabilności i przewidywalności w tym trudnym okresie ich życia, gdy struktura rodziny zmienia swój kształt. Taki plan daje rozwodzącym się rodzicom możliwość zapisania, a tym samym przestrzegania i realizowania wspólnie uzgodnionych zasad sprawowania opieki nad dzieckiem. Zasadą nadrzędną przy konstruowaniu takiego planu powinno być jak najlepsze zabezpieczenie potrzeb i interesów dziecka oraz umożliwienie mu kontaktu z obojgiem rodziców (o ile nie ma co do tego sprzeciwu sądu) na warunkach, które akceptują i zgadzają się przestrzegać oboje byli partnerzy. Rodzicielski plan wychowawczy zmusza rodziców do przemyślenia i przedyskutowania istotnych spraw z punktu widzenia życia porozwodowego, a zatem pozwala uczynić rozwód i okres po nim następujący mniej chaotycznym, bardziej przewidywalnym i zorganizowanym. Zachęca do merytorycznej dyskusji wolnej od uprzedzeń, walk, konfliktów i chęci zemsty oraz negatywnych uczuć złości i gniewu wobec byłego partnera. W planie tym podkreśla się konieczność 
omówienia przez rozwodzących się rodziców owych ustaleń z dziećmi i wysłuchanie tego, co mają do powiedzenia na ich temat. Na proponowany przez Centrum Mediacji „Partners” Polska rodzicielski plan wychowawczy składają się konkretne kategorie, do których rozstający się rodzice powinni się ustosunkować. Są to ustalenia dotyczące:

- miejsca zamieszkania dzieci (miejsca zamieszkania przez większość czasu, okoliczności spędzania czasu z każdym z rodziców);

- dni szczególnych w ciągu roku (urodziny, święta, rocznice, śluby, pogrzeby i inne okazje);

- szkoły i zajęć pozaszkolnych (szkolne wydarzenia, wywiadówki, zawody, imprezy szkolne, dowożenie do i odbieranie ze szkoły, decyzje dotyczące udziału dziecka w zajęciach pozaszkolnych);

- wakacji (czas wakacyjny dzieci - z kim dzieci będą go spędzały?, w jaki sposób będą ustalane plany wakacyjne?);

- opieki zdrowotnej (kto będzie odpowiedzialny za badania medyczne, dentystyczne, szczepienia itp.?);

- innych kwestii - np. zwierząt domowych, sportów, wycieczek szkolnych i innych wydarzeń istotnych z punktu widzenia rodziców;

- kwestii finansowych (ustalenia dotyczące finansowej opieki nad dzieckiem, kto będzie ponosił większe wydatki?, kto będzie finansował wakacje, wycieczki szkolne itp.?).

Całość rodzicielskiego planu wychowawczego kończą wnioski, zobowiązania co do przestrzegania ustaleń zawartych w planie, z możliwością ich weryfikacji i zmiany w przyszłości. Rodzice powinni zdać sobie sprawę, że tylko na drodze wzajemnej współpracy będą mogli dokonywać ustaleń, które w przyszłości zagwarantują im i ich dzieciom spokojną przyszłość (Piotrowska, 2015, s. 205-208).

Ważną formą wsparcia rodziców w sytuacjach rozwodowych są opracowane specjalnie dla nich warsztaty umożliwiające im nabycie kompetencji w zakresie radzenia sobie $\mathrm{z}$ emocjami dziecka $\mathrm{w}$ trakcie i po rozwodzie. Warsztaty dla rodziców to forma poradnictwa o charakterze grupowym. W ich trakcie rodzice nabywają wiedzę i umiejętności pozwalające im na udzielanie efektywnej pomocy dzieciom $\mathrm{w}$ procesie przechodzenia przez sytuacje rozwodowe. Bazując na aktywizujących metodach edukacyjnych, trenerzy prowadzący warsztaty stwarzają rodzicom okazję do przyjęcia perspektywy dziecka, dzięki czemu są w stanie uświadomić sobie ogrom ponoszonej przez nie straty i wyobrazić sobie uczucia przez nie przeżywane lub te, które będą ich udziałem, gdy rodzice się rozwiodą.

Bardzo ważnym ogniwem w systemie wsparcia rodziny i dziecka w sytuacji rozwodu jest szkoła: wychowawca klasy, pedagog. Prawidłowa diagnoza sytuacji dziecka w rodzinie po rozwodzie powinna implikować podejmowane wobec 
niego działania. Mogą one mieć charakter profilaktyczny, resocjalizacyjny, kompensacyjny, reedukacyjny, czy socjalno-opiekuńczy. Diagnoza sytuacji dziecka, odnosząca się do jego sfery psychicznej, emocjonalnej, społecznej, może stać się punktem wyjścia do opracowania przez wychowawcę/pedagoga szkolnego, programu oddziaływania wspierającego przy wykorzystaniu różnych metod pracy wychowawczej. Odzwierciedlać je mogą między innymi zajęcia dramowe czy warsztaty bajkoterapeutyczne - odwoływanie się do bohaterów filmowych czy literackich, którzy znaleźli się w podobnej jak dziecko sytuacji. Ważne jest budzenie nadziei na lepsze życie, zapewnienie dziecku możliwości osiągnięcia sukcesu sprzyjającego budowaniu pozytywnego obrazu siebie oraz motywowanie go do nawiązywania relacji koleżeńskich, przyjacielskich, a także rozwijania zainteresowań (Matyjas, 2017, s. 106-107).

\section{ZAKOŃCZENIE}

Rodzina niepełna, jaką jest rodzina rozwiedziona, nie zapewnia dziecku stałej dostępności obojga rodziców w wyniku zerwania lub ograniczenia relacji między małżonkami. Rozwód osieroca dziecko, dlatego jest tak bardzo dla niego wstrząsającym, tragicznym przeżyciem, wywołującym lęki, stany depresyjne, poczucie braku bezpieczeństwa, uczucie nieodwzajemnionej miłości, opuszczenia przez bliską mu osobę.

Warto jednak podkreślić, iż dziecko funkcjonujące w rodzinie rozwiedzionej nie zawsze musi odczuwać tę sytuację tak bardzo boleśnie, destrukcyjnie, traumatycznie, jak to ukazano w niniejszych rozważaniach. Ważny jest bowiem stopień zainteresowania dzieckiem przez rodzica, z którym ono zamieszkuje, preferowany przez niego styl wychowania w rodzinie, jak i stopień zaangażowania emocjonalnego $\mathrm{w}$ proces wychowania i opieki rodzica już nie mieszkającego z dzieckiem.

W kontekście rosnącego przyzwolenia na rozwody, które rozpoczynają długoterminowe zmiany w życiu człowieka nie do przecenienia jest profilaktyka rozwodowa $\mathrm{w}$ obrębie której ważne jest między innymi uświadamianie poważnych skutków rozpadu związków małżeńskich. Można to czynić poprzez publikacje, upowszechnianie rzetelnych danych, wprowadzenie obligatoryjnej mediacji w sprawach o rozwód małżonków mających małoletnie dzieci, rozwijanie poradnictwa rodzinnego, małżeńskiego i znaczne zwiększenie dostępności do niego (np. warsztaty dla małżeństw ukierunkowane na kształtowanie odpowiedzialności za trwałość rodziny, organizowanie konferencji poświęconych rodzinie, prezentowanie audycji radiowych, telewizyjnych dotyczących wartości małżeństwa i rodziny). 


\section{BIBLIOGRAFIA}

Beisert, M. (2000). Rozwód. Proces radzenia sobie z kryzysem. Poznań: Wydawnictwo Fundacji Humaniora.

Beisert, M. (1994a). Rozwód jako wydarzenie krytyczne w cyklu rozwoju rodziny. Problemy Rodziny, 2, 41-46.

Beisert, M. (1994b). Strategie zmagania się z rozwodem i jego następstwami. Problemy Rodziny, 6, 13-18.

BrąGiel, J. (2004). Długoterminowy wpływ rozwodu rodziców na dzieci. W: A.W. Janke (red.), Pedagogika rodziny na progu XXI wieku. Rozwój, przedmiot, obszary refleksji i badań (s.193202). Toruń: Wydawnictwo Edukacyjne Akapit.

CudAK, H. (2010). Zagrożenia emocjonalne i spoleczne dzieci z rodzin rozwiedzionych. Toruń: Wydawnictwo Adam Marszałek.

Czerederecka, A. (1999). Syndrom odosobnienia od jednego z rodziców u dzieci z rozbitych rodzin. Nowiny Psychologiczne, 4, 5-13.

IzDEBSKA, J. (2004). Dziecko osamotnione $w$ rodzinie. Kontekst pedagogiczny. Białystok: Wydawnictwo Uniwersyteckie Trans Humana.

KeIth, V.M., Finlay, B. (1988). The impact of parental divorce on children`s educational attainment, marital timing, and likehood of divorce. Journal of Marriage and Family, 50, 3, 797-809.

Matyjas, B. (2017). Dzieciństwo w rodzinie rozwiedzionej. Formy wsparcia psychologiczno-pedagogicznego rodzin po rozwodzie. W: M. Parzyszek, M. Samorańska (red.), Rodzina - wsparcie i pomoc (s. 99-109). Lublin: Episteme.

Melosik, Z. (2003). Pedagogika postmodernizmu. W: Z. Kwieciński, B. Śliwerski (red.), Pedagogika, vol. 1 (s. 452- 464). Warszawa: Wydawnictwo Naukowe PWN.

Melosik, Z. (1995). Postmodernistyczne kontrowersje wokót edukacji. Toruń-Poznań: Wydawnictwo Edytor.

NowaK, B.M. (2012). Rodzina w kryzysie. Studium resocjalizacyjne. Warszawa: Wydawnictwo Naukowe PWN.

NowaK-Dziemianowicz, M. (1994). Matżeństwo wobec rozwodu. Wrocław: Wydawnictwo Uniwersytetu Wrocławskiego.

Pohorecka, A. (1994). Czy dziecko musi być kozłem ofiarnym? W: A. Pohorecka (red.), Rozwód? Czy się rozwodzić? Jak się rozwodzić? Co po rozwodzie? (s. 90-115). Warszawa: Instytut Psychiatrii i Neurologii.

Piotrowska, M. (2015). Rozwód w rodzinie wyzwaniem dla współczesnego poradnictwa rodzinnego. Refleksje doradcy. W: M. Piorunek (red.), Dymensje poradnictwa i wsparcia społecznego w perspektywie interdyscyplinarnej (s. 201-210). Poznań: Wydawnictwo Naukowe UAM.

Rodzicielski Plan Wychowawczy. Porozumienie rozstających się rodziców (2009). Warszawa: Wydawnictwo Centrum Mediacji Partners Polska.

SEnATOR, D. (2010). Więź zdezorganizowana jako czynnik ryzyka patologii w dzieciństwie i dorosłości. W: B. Tryjarska (red.), Bliskość $w$ rodzinie. Więzi $w$ dzieciństwie a zaburzenia $w$ dorostości (s. 43-62). Warszawa: Wydawnictwo Naukowe Scholar.

Siewierska, A., ŚliwczyŃska, J., Misiec, M., NAmysŁowska, I. (2012). Więzi czy wiązania - przebieg procesu separacji międzypokoleniowej w rodzinach dorastającej młodzieży. W: B. Tryjarska (red.), Bliskość w rodzinie. Więzi w dzieciństwie a zaburzenia $w$ dorostości (s. 81-97). Warszawa: Wydawnictwo Naukowe Scholar. 
SoKal, U. (2005). Więzi uczuciowe dorostych dzieci z rodzicami w rodzinach rozwiedzionych. Elbląg: Wydawnictwo Elbląskiej Uczelni Humanistyczno-Ekonomicznej.

Stojanowska, W. (1997). Ochrona dziecka przed negatywnymi skutkami konfliktu między jego rodzicami. Warszawa: Wyższa Szkoła Pedagogiki Specjalnej im. Marii Grzegorzewskiej.

ŚLIWERSKI, B. (2004). Współczesne teorie i nurty wychowania. Kraków: Oficyna Wydawnicza Impuls. Wallerstein, J.S., BlakesLeE, S. (1989). Second chances: Men, women and children a decade after divorce. New York: Ticknor \& Fields.

WolchiK, S.A. i in. (2002). Six-year follow-up of preventive interventions for children of divorce a randomized controlled trial. Journal of American Medical Association, 285/15, 1874-1881.

\section{DZIECKO W SYTUACJI ROZWODU RODZICÓW}

\section{STRESZCZENIE}

Rozwód jest wydarzeniem przełomowym w życiu każdego członka rodziny. Można go rozpatrywać w perspektywie indywidualnej, diadycznej i rodzinnej. W niniejszym tekście rozpatrywany jest głównie w kontekście rodzinnym i najmłodszych członków tejże wyjątkowej wspólnoty. Dla dzieci rozwód oznacza utratę pełnej rodziny i wiąże się z szeregiem - traumatycznych dla ich funkcjonowania - bezpośrednich i odroczonych w czasie skutków rozwodu rodziców. Szczególnym wymiarem sytuacji rozwodowych sa , przetargi o dziecko” we wszystkich fazach procesu rozwodowego. Będąc obiektem manipulacji, indoktrynacji i instrumentem w konflikcie rodziców, dzieci doświadczają ogromnej krzywdy - bolesnych uczuć, niezaspokojenia ważnych dla swego rozwoju potrzeb. Dlatego też nie do przecenienia jest wspieranie rodzin i ich dzieci w sytuacjach rozwodowych. Wybrane przykłady form wsparcia psychologiczno-pedagogicznego we wskazanym aspekcie zamykają rozważania dotyczące jednego z najtrudniejszych problemów życia społecznego oraz jednego z największych zagrożeń współczesnej rodziny.

Słowa kluczowe: dziecko; rodzina rozwiedziona; skutki rozwodu rodziców; formy wsparcia.

\section{A CHILD IN THE SITUATION OF PARENTS’ DIVORCE}

\section{SUMMARY}

Divorce is a significant event in the life of every family member. It can be considered from individual, diadic and family perspectives. In this text it will be considered mainly in the family context and in relation to the youngest members of this unique community. For children, divorce means the loss of a complete family and involves a number of immediate and deferred effects of the parents' divorce that have a traumatic impact on their lives. A particular dimension of divorce situations is "bargaining for the child" in all phases of the divorce process. Being an object of manipulation, indoctrination and a tool in the parents' conflict, children experience great harm painful feelings, a failure to satisfy needs important for their development. Therefore, it is invaluable to support families and their children in divorce situations. Selected examples of forms of psychological and pedagogical assistance in the indicated aspect close the considerations on one of the most difficult problems of social life and one of the greatest threats to the modern family.

Keywords: child; divorced family; consequences of parents' divorce; forms of support. 